\title{
Narratives of Racial Reckoning: Oppression, Resistance, and Inspiration in English Classrooms
}

\author{
Joanelle Morales* \\ Nick Bardo \\ Colorado Mesa University \\ *Corresponding Author: jmorales@coloradomesa.edu \\ Received : 2020-9-18 \\ Accepted : 2020-12-16
}

DOI: $10.46303 /$ jcve.2020.17

How to cite this paper: Morales, J. \& Bardo, N. (2020). Narratives of racial reckoning: Oppression, resistance, and inspiration in English classrooms. Journal of Culture and Values in Education, 3(2), 138-156. doi.org/10.46303/jcve.2020.17

This is an Open Access article distributed under the terms of the Creative Commons Attribution 4.0 International license (https://creativecommons.org/licenses/by/4.0/)

\section{Abstract}

This narrative inquiry traces the experiences of five racially and ethnically diverse English Language Arts teachers as they move from their university coursework in a teacher education program to their student teaching and then into their first years teaching in a large urban school district in the Southeast. Through narrative inquiry, these teachers describe how language was/is used as a tool of racial oppression in their professional lives, how language served as resistance to racist discourses in their classrooms, and furthermore how language functioned to inspire through the disruption of racist discourse. These narratives illuminate the intersections of race, ethnicity, language, education, and power and how teachers can both disrupt and sustain canonical narratives and discourses.

Keywords: English language arts, narrative inquiry, teacher education

\section{Introduction}

Four years ago, I taught my first English Education course at the pseudonymously named Laurel Oak University titled "Methods of Teaching English in Secondary Classrooms: Practicum." What stood out to me the most, beside the blunders and nervousness of teaching preservice teachers for the first time, was a conference meeting I had with a student who expressed a genuine frustration: "I feel like the College of Education did not prepare me to teach this population. I was at a loss trying to figure out how to connect to the students." We discussed how she felt disillusioned because her expectations were not met, how her own schooling experiences did not align with her students, and how unfair it was to observe how the educational system failed the marginalized students. As a White American, it was her first time in a classroom where racially and ethnically, she was the minority. Everything seemed foreign, and the methods to teach the racially and culturally diverse population escaped her. This is not uncommon. 
With the steady growth of a racially and ethnically diverse student population in the U.S., projected by 2029 to comprise 56\% of total public elementary and secondary school enrollment (National Center for Education Statistics, 2020), it makes sense to demonstrate how language functions by shaping the myriad discourses surrounding the act of teaching and learning, specifically in regard to race and ethnicity, in the secondary English language arts classroom. Research has overlooked the voices and complex racial stories of preservice secondary English teachers of color, which could be valuable in understanding how to teach race and racism through English language arts in the college and secondary levels.

Hollins (2012) reported preservice teachers often feel inadequately prepared to teach students from diverse backgrounds. One reason, Sleeter (2001) suggested, is that White teachers cannot relate to their students' racial backgrounds. When preservice teachers are unable to be cultural brokers between home and schools, they become ineffective in instructing their students of color (Villegas \& Lucas, 2002). My conversation with this student renewed my previous interest towards race and teacher training. The majority of our teachers are middle class White American women (National Center for Education Statistics, 2020), so I wondered: How do preservice teachers, White and non-White, conceptualize race? What are the stories behind their conceptualizations? Do these stories of race influence their pedagogy? If we become more cognizant of how the discourses constituting race plays a part in education, would we be able to better prepare preservice teachers to teach culturally diverse students?

As a Pilipino ${ }^{1}$ immigrant student who later became a high school English teacher, I wondered why I never thought of these questions before. Even though I had always recognized being Asian played a part in people questioning my credibility as an English teacher in a predominantly White workforce, I insisted the topic of race did not matter in the classroom. I was not conscious of race's role as a means of how power is distributed in the educational system, I rarely discussed it, and I am sure I did not implement teaching practices that empowered students through their cultures or what Gay (1999) and Ladson-Billings (2009) would call "culturally relevant pedagogy". Instead, I imitated what I learned in school and in observations, unknowingly supported normative teaching practices informed by Eurocentric social constructions, knowledge, and behaviors (Lee, 2013). Essentially, I unknowingly perpetuated a hegemonic curriculum and mode of pedagogy based upon the norms of the dominant White racial group.

In this study, I began to look at the complexities of the ethnic, racial and cultural incongruence between teachers and their students, which lead to an analysis of our ethnoracial identities and their relationship with discursive formations expressed through stories. Despite being an Asian-American with an immigrant background, I was unconscious of how race or ethnicity ${ }^{2}$ played a role in my narrative of teaching. I internalized the notion that English literature and the English language and ultimately, White American culture was superior. Critical discussion of race did not belong in the English classroom. But, what if

\footnotetext{
${ }^{1}$ A way to reclaim the identity of a person from the Philippines from the colonized label of "Filipino" (Kohli, 2019).

2 I use the terms "race", generally defined in terms of biological and physical characteristics, and "ethnicity", generally referenced as groups characterized in terms of common nationality and language, as related concepts associated with culture (Betancourt \& Lopez, 1993).
} 
teacher educators made preservice secondary English teachers critically conscious of racial discourses and how it factored into their pedagogical decisions and worldviews before they set foot in their future classrooms? Could reflecting on these discursive formations determine how they would accept or reject the status quo of the ELA (English Language Arts) curriculum and teaching practices? Through narrative inquiry, I explored the following research questions:

1. What were the stories behind the beliefs, attitudes, and experiences with regard to race and ethnicity of four secondary English teachers?

2. In what ways did their perceptions of ethnoracial identities inform their practice during their practicum, internship, and first year of teaching?

Because I positioned myself as a central participant within the story, I also explored the following:

3. How did the English teachers' stories about race and ethnicity affect my own understandings of my past to inform my present career as a teacher educator in English Education?

In exploring these questions, I found ways in which discourse surrounding race oppressed, resisted, and inspired ways in which these future teachers and myself approached teaching and learning in both teacher education classes and their first years teaching.

\section{Purpose of the Study}

I aimed to contribute to the body of knowledge on English teacher education and Preservice Secondary English Teachers' (PSET) critical examination of race. Research has suggested that substantive discussions of race and racism are often missing or deemphasized in preservice teacher preparation programs (Sleeter, 2017; Matias \& Mackey, 2016; Milner, 2017; Ladson-Billings \& Tate, 1995; Solorzano \& Yosso, 2002). The purpose of my study was to explore preservice secondary English teachers' understandings of the complexities of race and racism in education. I aimed to reveal their discourses regarding how they construct and make meaning of their ethnoracial identities and how these identities related to their beliefs and practices as English teachers. I investigated these connections by following them in their journey in the profession. I did this by interviewing the participants before their field experiences and listening to their stories of their racial experiences in education, including accounts of discrimination, self-blame, or invisibility. I observed these individuals in their practicum and re-interviewed them after their internships and their first year of teaching to discern whether and how their subsequent narratives revealed changes in perspective in relation to race in education. Did their consciousness of racial discourses play a role in their practice?

Studies conducted by Bieler (2006) and Kirkland (2014) have addressed preservice teachers' perspectives on race, these studies have foregrounded the voices of White teacher candidates. Yet, research remains to be done on how preservice teachers of color also narrate the intersection of their racial identities and their experiences of teaching and learning, especially in English Education. I highlighted English language arts Education because it is a discipline that often gets misinterpreted as a course that endorses division and exclusion, where "proper English" or "canonical literature" frequently favors White male perspectives and values, maintaining a marginalizing status quo (Gere, 1992; Borsheim-Black, Macaluso, \& Petrone, 2014). However, I argued the ELA classroom is quite the opposite, not at all insular 
as some may presume and can actually serve as a rich space to welcome all sorts of languages and cultural backgrounds, inspiring a rationale for inclusion and greater awareness.

\section{Theoretical Framework}

Stuart Hall's interpretation of Michel Foucault's discursive formation is applicable to the nuanced ways in which knowledge/power applies to everyday life and disciplining how teachers act, talk, and reflect in relation to race (Laclau, 1997). According to Stuart Hall (2001), a discursive formation can be summarized as follows. First, statements are made about a topic by a dominant group, statements that create an "official" knowledge about the said topic. Secondly, Hall describes "rules" as created prescribing ways of talking about the chosen topic and excluding other ways. These rules also govern what is "sayable" or "thinkable" about the chosen topic at a particular historical moment. Third, subjects in some way embody or personify the attributes of the discourse. After that, the process of how this knowledge acquires authority or a sense of embodying the "truth" must be pinpointed. What are the institutional practices for dealing with the subjects, whose conduct is being regulated and organized according to the "rules"? Finally, Hall acknowledges the historical context of any discourse, citing that a different "truth" will arise at a different historical moment, replacing the existing one, and opening up a new discursive formation.

Following this discursive epistemological and ontological starting point, the methodology of narrative inquiry is appropriate. Through presenting narratives of participants as findings, what is "told" is already a "node within a system of nodes" according to Foucault (1972). In other words, for a participant narrative to enter into representation, the possibilities of the narrative are bounded by discursive knowledge in which the narrative functions. That is to say, these molding forces in many ways have already "told" the story before it is told by the participant - the findings underscoring how powerful discourses related to race in the classroom oppress, resist, and inspire in how they are told.

A critical literacy framework is also appropriate for considering narratives about race and ethnicity related to the preparation of teaching preservice English language arts teachers. Critical literacy, which focuses on how language practices maintain and disrupt power, is an additional approach to social justice in the ELA classroom. English teachers, who use reading and writing as the medium to account for multiple differences situated in a particular sociocultural context (Jocson, 2009), benefit from using the critical literacy framework to encourage analysis of how people use language to confront injustices. This analysis allows students of English to examine how cultural discourses work in terms of agency, how language shapes identity, how words and grammar work to privilege certain groups, and how to interrogate classroom tasks by asking about author's intentions towards particular audiences (Guzzetti, Young, Fyfe, \& Hardenbrook, 2002). Boyd et al (2006) adds that "Freireian critical literacy is a fundamental teaching objective in all ELA classrooms...if learners do not come to understand that the language they're learning about can be their own language, they'll continue to be mere serfs to those who 'own' the language and the culture of power" (p. 331). These powerful and purposeful statements assisted me in critiquing the literacy practices English educators perpetuate in teacher preparation programs. 


\section{Critical Race Literacy}

I extended the notion of the importance of critical literacy in ELA classrooms with the addition of critical race literacy. Why English teachers don't explicitly address or teach race is puzzling because ELA teachers are expected to help develop student voice by empowering their sense of identity through language. Questions like, "How does language maintain power?" should be discussed and explored. ELA teachers have the responsibility to teach critical literacy skills, but many times critical race literacy is bypassed due to how educational systems are designed. The educational system in the U.S. reifies cultural practices and ways of knowing and being of the White majority (Milner, 2017). It encourages the myth of meritocracy, perpetuate deficit mindsets, and colorblindness. Preservice secondary English teachers' and in-service English teachers' lack of critical race consciousness and inability to address racial issues in their classrooms result in children of color being perpetually underserved. With the gain of popularity of culturally relevant pedagogy, Milner (2017) argued race should be its "integral core" (p. 2).

Hall et. al (2010) posited that negative literacy experiences can influence how preservice teachers identify themselves as literacy teachers. They found attempts to gain "identity capital" affect how students learn to read and write, that students could adopt language and speech patterns to position themselves as a certain type of person. Deconstructing this notion of privilege as prospective ELA teachers can result in rethinking and transforming the English curriculum and pedagogy in ways that can empower racial identities rather than marginalize them.

\section{Literature Review}

To understand the ways in which others have approached the issue of conceptualizing personal and professional racial discourses relative to the secondary English language arts classroom, the following section provides an overview.

Understanding "racially just teacher education" requires understanding the implementation of Freire's (1989) language of critique, the ability to critique society but maintain humility, compassion, and tolerance. As facilitators to help their White preservice teachers confront racism, Marx and Pennington (2003) discovered that Freire's notion of dialogue generated constructive and respectful conversations. Matias and Grosland (2016) advised to embody an ethics of care when deconstructing Whiteness because although one must have the fortitude to withstand the discomfort of self-interrogation, one must avoid becoming myopic. Bissonnette and Glazier (2016) have found through their research that cultivating a caring relationship with their students was the most effective way to demonstrate critical race theory in practice. Echoing Gay (2010), Bissonnette and Glazier (2016) believed teachers must first forge relationships with their students by being as open and vulnerable by offering their own counterstories. Sharing one's anecdotes about racism was particularly helpful for Marx and Pennington (2003) who believed doing so helped establish trust among their students and thus created a more constructive conversation.

Grant and Agosto (2008) warned educators to not patronize their students in order to prevent even further resistance in meaningful engagement when deconstructing Whiteness. Marx and Pennington (2003) found that they had to remind themselves that many of their participants had little experience talking critically about race, so it was important not to 
become offended. Strategies that open up uncomfortable but necessary racial discussions require an empathetic and supportive disposition.

At the same time, teachers and students must be made aware of potential pain when examining one's self. Lac (2017) referenced Malcolm X's famous line, "The examined life is painful" (p. 15), to summarize her analysis of her students' reflections on institutionalized racism. The process of becoming more critically conscious of one's historical-socio-political positioning in the world can lead to unpleasant reckonings but may also lead to a sense of empowerment. Marx and Pennington (2003) learned that their participants felt at first debilitated by their recognition of White privilege, but then eventually moved on to firm resolves as antiracist educators.

This review of literature contextualizes how disrupting oppressive ethnoracist discourses in classrooms can serve to resist and inspire educators and students alike. Drawing upon this vein of inquiry, the narratives presented in this study further contextualize what some of these practices resemble from the teachers in the classroom.

\section{Data and Method}

I employed narrative inquiry (Clandinin \& Connelly, 2000) as the qualitative research method because it allowed me to not only tell my participants' stories, but also because I felt it necessary to include my own personal story. How have I conceptualized racial discourses as a teacher and a teacher educator, and how has this conceptualization changed over time?

The narrative inquiry approach was appropriate because it offered an opportunity for participants to narrate their ethnoracial identities in conjunction with their ELA teacher identities and share how certain events in their lives have shaped their normative world views in regard to discourse surrounding race. This knowledge can be valuable for English teacher educators interested in incorporating critical race literacies and pedagogies in their programs.

By critically analyzing their narratives, prospective English teachers can confront foundational questions like "What makes good literature or writing?" and "Who gets to determine what is good literature and what is good writing?" PSETs could analyze the power of language and how it was manipulated to sustain those in power and demean those who are not. These conversations could lead to a more inclusive ELA instruction and a racial justice pedagogy.

\section{Sample}

I recruited my participants by sending an email after teaching the Methods of Teaching Secondary English to 18 students enrolled in the course. I made clear this was a voluntary research which meant they could choose to participate or withdraw anytime as part of the informed consent process. I obtained IRB permission and employed convenience sampling to determine who would be available for the study. After six students expressed interest, I then purposefully selected four students from this initial pool of respondents due to their different racial backgrounds in response to the lack of literature representing narratives beyond the White/Black binary (Kohli, 2013).

\section{Data Collection}

I scheduled four one-on-one interviews with each participant at three points over the course of two years. Each of the four participants were interviewed before their student 
teaching internship began, again after their internship, and once more during their first year after graduating. I used a semi-structured interview protocol in order to elicit rich, individual stories. Each interview averaged an hour in length, resulting in 150 pages of typed transcripts in total. In combination with the artefactual data, which included classroom observation notes, teaching philosophies from the methods course, lesson plans, and heuristic artifacts that helped them conceptualize race during the interview provided grist for analysis.

\section{Data Analysis}

Given the interplay between the present, past, and future in terms of making meaning, data through the lens of qualitative research is perpetually in the process of analysis (Glaser, 1965). This tension was operationalized as a coding method put forth in grounded theory termed "constant comparative" coding (Strauss \& Corbin, 1997). Considering the constant comparative method, there is an acknowledgement that the researcher is always making sense of the data, "building the narrative" in their mind before any official analytical stage is broached. Narrative methods are rooted in this non-linear and iterative process of data analysis (Connelly \& Clandinin, 1990). In this methodological approach, there is not a proscribed structure with more positivist leaning qualitative methods like those put forth by Maxwell (2012). That being said, specific analytical attention was paid to the research questions through a re-storying process.

\section{Re-storying}

To re-story, the data collected was arranged in chronological sequence and thematically coded for narrative structure by the researcher. This involved arranging the collected data and taking margin notes for initial organization purposes. From these notes, the bones of a narrative "through line" were ascertained to anchor the re-storied narratives, provide character descriptions, and also a discernable plot that aligned with the research questions (Connelly \& Clandinin, 1990). Through this process, I placed myself and my own data into the narrative. This interplay between the researcher and participant data spoke to the collaborative meaning making process of the project and also the innate subjectivity of the researcher's interpretation.

\section{Results}

The following narratives highlight how the participants' and researcher's ethnoracial beliefs, attitudes, and experiences demonstrated how language in the English language arts classroom served as a force of oppression, resistance, and inspiration in regard to racial discourses through their personal history, teacher education coursework, and in their first year experiences teaching in the field.

\section{Language as Racial Oppression}

The following narratives demonstrate how discourses surrounding race served to oppress students in the context of the English Language Arts classroom. Themes including immigration, pronunciation, bullying, and representation underscore the nuanced ways in which language marginalizes. With my participants, I addressed our adapted worldviews and our personal histories behind them by sharing my own family stories and struggles with conceptualizing race in order to build a rapport conducive to honest narratives. 


\section{Joanelle}

As an immigrant student learning English, I felt how language often served as an oppressive tool that reinforced racial discourse. I remember it was time to read aloud our class novel, Little House on the Prairie by Laura Ingalls Wilder. By this time, I had finally been released from the ESOL (English as a Second Language) program and had read most of the Judy Blume, Beverly Cleary, and E.B. White books from the local library. Feeling confident, I eagerly raised my hand to volunteer to read. My intonation was accurate, my execution of dialogue was playful, so it sounded like I knew exactly what was going on in the story. Then I came to a word, a two-syllable word. I knew its meaning. I can picture it on the front of the book. I read it the way it was spelled. Wagon, the horse-drawn carriage with a cover to protect the little bonneted girls who were off for some adventures on America's frontier. Wagon, with a long a.

Snickering.

Giggling.

I stopped myself. An embarrassingly extended pause settled until the teacher clarified, "it's wa-gən" (emphasizing on the phoneme, the short a /a:/). The memory of mispronouncing "apple" when I was in second grade flashed in my brain again. Hadn't I learned my lesson? I was suddenly angry at apples that my family never ate at home and the wagon that never entered my parents' lips. But most of all, I was angry at myself, for still falling short in researching the English language and the entirety of American history and culture. I was even more determined to become Americanized by diving into American books, hoping to resurface less Pilipino and be fully accepted among my White friends. I wanted to understand the idioms, relate to the characters, and empathize with their problems.

There is a big problem with this picture.

As charming as Laura, Mary, and Carrie were, they were not my people, not my past. The characters in the R.L. Stine stories and the Goosebumps series were the pre-teens and the teens I watched hungrily on TV, shows like Boy Meets World, Full House, Dawson's Creek. But these were not my people; they did not have my problems.

In hindsight, I reflected that in the midst of White culture, I seemed to have lost my place. My voice was only heard if it contributed to the normative discourse. I internalized that my Pilipino-ness did not matter, and I subconsciously rejected my culture, my language, and my family.

Freire (1970) would describe my internalized racism as oppression and lack of critical consciousness. When the dominated is subjected to a hierarchy of power for a long time, they deem their native culture worthless and wish to embody the culture of their oppressor (Freire, 1970). It is important that teacher educators provide space for prospective teachers to critically reflect upon or heal from their experiences of internalized racism, to unpack their belief systems, and unlearn deficit perspectives (Kohli, 2013).

\section{Ariana}

Ariana identified herself as a Black female in her early 20s who comes from a low socio-economic background and lives with her grandmother. She shared a story from her internship about a Vietnamese student, Mai, who was bullied by a Black girl, Kali. Mai was losing weight, and it was apparent she was not eating lunch with the others. Everyone assumed she was anorexic, but behind the scenes, Kali was taking her food. When the situation was finally addressed, Ariana was able to talk with both Kali and Mai. Mai said she 
readily gave her lunch to Kali because Kali was "aggressive", and Kali explained that Mai was "too passive". At this point, Ariana agreed with Kali; Mai should have been more assertive. When Ariana told Kali that what she was doing was bullying Mai, Kali said, "Well, it's ok, right? We're supposed to be aggressive." Ariana asked, "Where'd you learn that from?" Kali responded, "You know, from movies." This event illustrated how negative stereotypes of Black women played out in Ariana's classroom and how both Kali and Ariana's internalization that Black people are more aggressive affected the interaction. It was also interesting that Ariana was hypersensitive towards the stereotype that Black people are criminals or thieves. Although eventually the situation was resolved, it was evident some unlearning of deficit perspectives was necessary.

I think the problem was Ariana never had the space and opportunity to interrogate her own narratives (Kohli, 2013). She had not purposefully questioned the powers that brought tacit racism her family, her church, and she, herself, may have adopted. For example, Ariana tolerates the use of the n-word between "old people" from church, White friends, and Black students. The angry Black woman trope often play into her stories but are not confronted. Ariana would rather avoid the topic of race in her English classroom, unknowingly suggesting that assimilation and suppressing one's Black identity was the best chance for success. Hence, home language was dissuaded in speaking and writing, and Black stories and experiences were de-emphasized.

Regarding the previous story about Kali and Mai, Iftika \& Museus (2018) claimed the valorization of Asian Americans relative to Black communities contribute to the internalization of anti-black perspectives and reinforcement of White supremacist ideology. They suggested this thinking might inform decision-making that reinforces systematic racial inequities, perhaps in the classroom. The model minority category might hinder the development of Asian Americans' critical consciousness and racial justice advocacy for other communities of color, even fuel anti-Blackness (Iftika \& Museus, 2018), and pit the two groups against each other.

\section{Georgia}

Georgia identified herself as a Caucasian female in her early 20s who has expressed interest in culturally relevant pedagogy due to her conflicting understandings of how her families perceive ethnicities and race. Georgia conducted an activity that involved students creating character maps for the characters in Amy Tan's, The Joyluck Club, a novel about four Chinese American immigrant families. Georgia recounted, "I had several students who decided to be funny and draw the characters with really exaggerated slanty eyes and yellow skin. One kid asked me if he can draw a character eating a cat. I said, 'That's not appropriate. Did she eat a cat in the book?' He said, 'No,' so I said, 'Then you may not.' 'Well, can I draw her eating a dog then?"' Here, she argued the racist act of drawing stereotypical characteristics on a class assignment was "inappropriate" because there was no textual evidence to say that's what the character looked like. Georgia did not have to offend the student by calling the inquiry a racist act and instead simply referred to an ELA standard of finding supporting evidence to make a claim.

During her internship, Georgia also had her students create character maps, this time developing a "hero" that aligned with the Greek mythology unit. "I had a kid who said he was gonna name his character Donald Trump and for his personality, he wrote 'racist,' and I said, 'Ok, we need to reel this back in, this is not an opportunity for you to get silly, this is a project 
you'll be presenting in class.' He said, 'I don't understand what the big deal is.' And I said, 'It's not ok to be racist, it's not kind."' Here, she addressed racism as inappropriate because it is not kind and thus not worth presenting to the class. She told the student to create another "hero" in which he obliged. Again, the student was not confronted for thinking being racist was some sort of a heroic quality, but Georgia's strategy of calling racism "unkind" prevented any type of conflict.

Safe topics may not properly represent marginalized students and thus perpetuate the dominant culture rather than challenging or resisting it (Bender-Slack, 2010). Comber (1999), accounting for one ELA classroom exploring critical literacy, argued that educators fear critical analysis will spoil children's fun by "brainwashing" them with their own ideology, which defeats the purpose of "emancipatory education" (Freire, 1970). She continued that teachers often argue children may not be mature enough to tackle these controversial topics and when do they begin to understand the scope of "seriousness," it may make them cynical. However, her narrative suggested if we encourage students' interest to drive critical literacy as they discuss how texts work by positioning their thoughts and ideas in the center of the lesson, they could take ownership of their learning (Comber, 1999).

Georgia recalled a time when she heard students singing "Build a wall!" in the hallway. She took one of her students aside to reprimand him. She described, "He and I had a discussion about why that wasn't respectful coz there are kids in our school who would take offense. We need to be more conscious of people around us because we don't know their backgrounds, we don't know where they come from. 'Build a wall' is not a kind thing to say." I asked her if what she said affected him, and she claimed she didn't hear him say it anymore (at least out loud where she can hear). However, she remembered another time when she confronted another student about a racist remark: "We have a Chinese teacher down the hall and every time she comes out, the kids would yell, "Ching ching chong!" So one day I scolded one of my students, 'That's enough, you need to apologize to her right now coz she heard it,' and Ms. Koo looked at him and waited, but he didn't apologize. I was mortified, and she just walked away. She's very zen that way (giggles)." She was concerned because someone heard the offense, demonstrating the pattern of apologizing when you get caught. Georgia curtailed the racist action but again did not address the racist issue.

As can be seen from the stories above, the ways in which racialized discourses serve to oppress do not have a singular disciplining force, rather they operate in myriad ways. In a similar vein, language can also serve as means for counter stories, an important facet of implementing critical race pedagogies that serve to interrupt and resist dominant racist discourses.

\section{Language as Resistance}

Beyond racial oppression, language can also serve to resist hegemonic racial discourses that may oppress. The following findings highlight how methods teachers encourage critical reflection on ethnoracial positionality in relation to language, and how oppressive discourse can be addressed in the English language arts classroom.

\section{Joanelle}

During another session in my Methods class, I recalled a passionate debate regarding whose discourse belongs in the English classroom. One student argued, "It is our duty, as English teachers, to tell our students that they're speaking improper English. If we want them 
to succeed in college or in the professional world, they can't use slang or "ain't" or talk in their "ghetto" language."

His classmate quickly retorted, "Who are we to judge the way they speak? Aren't we essentially telling them their families and communities don't matter? You're diminishing their identities and berating their cultures. Have you never been around other cultures before?"

Another student chimed in, "Perhaps what he's trying to say is that our students need to learn how to code-switch. I mean I don't talk to my grandma the same way I talk with my friends." And another argued, "Maybe, as English teachers, we can welcome their cultural discourse, but critique their writing..."

This discussion went back and forth even through break. The students were heated in the debate because they wanted their voices heard. More importantly, they were thoroughly engaged in the process of grappling with what they thought they knew and what they were hearing from their classmates about their purposes in their future careers. This conversation gave us the opportunity to be honest with each other while at the same time allowed us to challenge our preconceptions. We began to look at how the debate connected to the institutionalization of White supremacy in English teaching expectations.

A few weeks later, after participating in a privilege walk, a kinesthetic activity that allow learners to recognize their powers and privileges over others, and debriefing Peggy Mclntosh's (1989) "Unpacking the Knapsack of White Privilege" through a Socratic seminar, my students unraveled some deep connections they made regarding this topic and reflected how important it was for English teachers to understand where their students are coming from in order to begin to teach their lessons. The activity began with a few seconds of fidgeting and side-eye glances because it seemed no one wanted to start a potentially contentious conversation. However, one student, usually outspoken but contemplative, was itching to say something. Finally, he sighed a dramatic sigh and announced, "Ok, I'll start. So, I really hate reading sh*t like this, because come ooooon! I'm not stupid, I know it happens sometimes, but not aaaallll the time!"

As the teacher watching from the outside circle, I tried not to show my eyes popping out in response. Though I was a little thankful the conversation started with this comment, I anticipated an explosive and angry backlash. Thankfully, the comeback was civil, but serious. An older White woman, who was also outspoken, calmly retorted, "You are a White man, of course you would say that. You can't possibly see the microaggressions people of color experience every day."

Maybe because we were in an intimate circle, maybe because everyone had already taken notes in preparation of what to say, maybe because this cohort was already comfortable with each other, or maybe because together we have set expectations about how to respond to each other's opinions, I was pleasantly surprised by how the conversation flowed. No punches were thrown or no one stood up and left in defiance. Instead, my Black student, the only Black student in the class of 25 , who is usually meek and reticent, spoke up, turned to him, and asked him, "Do you know how many times I've been told 'You're pretty for a Black girl?"”

Genuinely aghast, he said, "What? Really?"

A Central American student, also usually more reserved, piped in, "Every day I have to remind my own children to stay focused despite the racial remarks they are affronted with so 
they can show them, the other students, their teachers, that they are just as competent or even better. Why do I have to do that?"

Students chimed in with their thoughts and their experiences, and with the time we allotted for the activity, we had a tremendous amount of learning and self-reflecting that I hoped would inform our actions and teaching. At the end of the activity, the male student wrote me a reflective note admitting he still had issues with confronting his privilege, but was happy to be part of the conversation as it was eye-opening about real lived experiences of others.

\section{Genevieve}

Genevieve identified herself as a Lebanese-American female in her early 20s who grew up in a small town. She talked about how in her practicum, a teacher told her that she gives a student extra time because he's Black. Genevieve commented, "I had no idea where she was coming from. I just started the program and didn't know if I was allowed to say anything. NOW I'd be like, 'Why???' Back then, I was like, 'Oooh, maybe I shouldn't say anything.'" She then remembered observing a student saying in a class discussion, "Well, I don't understand why Black people can't dig themselves out of the slums," and the teacher dismissed the comment without addressing it. Genevieve struggled with this because she felt she didn't have the voice to make an argument. However, she did find her voice when she confronted a substitute, who was probably a lot less professionally intimidating than her cooperating teacher: "There was this sub, I don't think she realizes how racist she sounded. She's talking about African-American English or Ebonics or however you wanna call it. She was saying, 'I don't know why teachers let them talk like that,' and I was like, 'There's a time for informal and formal language,' and was trying to be civil with her. Then she has the audacity to be like, 'I don't agree with speaking ghetto,' and I was like, 'Gasp, excuse me?! No, I'm sorry I don't like that word. Nobody uses that word,' and she was like, 'Then what do you use?' Then, she had students speak like her, 'Oh, I learned it from the sub,' and I'm like, 'No, we don't talk like that!'” This set a precedent to her students that one should be accountable for the language they use and the knowledges they bring into the classroom. The event displayed a sense of intolerance for ignorance in the learning space. This resistance can empower students by understanding multiple Englishes and their cultural spaces (NCTE, 2018).

Taking the above narratives a step further, resisting ethnoracist narratives, representation, and language can yield inspiration when put into practice by English teachers dedicated to critical consciousness. One such teacher, Orlando, brought his racialized experiences to the classroom to inspire students through challenging dominant discourse.

\section{Language that Inspires}

Freire's theory of conscientização, or critical consciousness, which engages learners to analyze systems of inequality (Freire, 1970), was relevant to thinking about how language functioned to inspire in the stories of the participants. As the participants examined their realities and the development of discourses surrounding race, they began to evaluate how their exploration may have impacted their pedagogical practices. Were they promoting a racially just education, or were they maintaining an oppressive, racist system? 


\section{Orlando}

Orlando identified himself as a Puerto Rican male in his early 20 s who struggled to come to terms with how schools disenfranchised students with different cultural backgrounds. He narrated, "So in one unit, we read I am Malala: The Story of the Girl Who Stood Up for Education and was Shot by the Taliban and discussed globalization, like why should they even care about what's going on in other countries? And at one point, a student said, 'Oh, well they breed over there like rabbits.' I addressed this retort with the student and told him, 'You know you need to watch out, there are other cultures in our class, and we need to be sensitive to that coz we're all here working together.'" His reprimand reminded me of how Georgia handled insensitive comments, but to me, the difference was he added "we're all working together" to emphasize unity rather than imply division.

Orlando explained, "Maybe this is the wrong thing, but I stop class to take a student aside to talk to them if they have a personal issue. I don't care if I stop the class coz my priority is you and your success, so I kinda make them feel like they're more important than the lesson going on, because if I focus on the lesson, and be like, screw what the students are feeling, they're gonna act crazy while doing the lesson, they won't letme do the lesson. If a kid wants attention, they're not gonna let you do that lesson." I admired how he nipped it in the bud as I usually need time to think about my course of action when an unpopular view starts a debate. Orlando continued, "Essentially, I let them say what they wanna say, let them express how they feel. So for example, we had a Socratic seminar during the Chavez unit. There were some racist things said on both sides, from the Mexican kids and the White kids, but it lets them get their real beliefs and thoughts, and they came to a common ground, and they saw that there were some fear that they had thought about each other, like White kids felt the Mexican kids were taking their jobs, and they found that out, I didn't teach that, they taught themselves that!" He was truly amazed and proud of his efforts in creating an environment where students were open with each other and counterstories were applied effectively to better understand each other (Milner \& Howard, 2013).

Orlando utilized counternarratives that challenged majoritarian stories and represented legitimate knowledge that name the "others'" realities (Ladson-Billings, 1998; Lac, 2017). Doing so helped raise his students' critical consciousness and simultaneously, build upon his own.

Did Orlando get scared of resistance? He answered this, "Every time I get scared, I like, go say something to my AP, and he would say, "You gotta do that." I saw this incredible support to strengthen racial literacy as another factor to successful implementation of social and racial justice instruction. It can be a powerful force for our preservice teachers, our first year teachers, and even teacher educators to continue the work of anti-racist education, and it assists in resisting question of place in the profession (Sealey-Ruiz, 2011 as cited in Kohli, 2019).

Orlando's experiences in his practicum and internship demonstrated the need for a critical professional development that could provide a space to reveal biases, engage in reflexivity and racial literacy, and interrogate one's positioning (Kohli, 2019; hooks, 1994). Again, teachers need to evaluate their biases and determine how they impact their practice.

As can be seen in Orlando's experience described above, dialogical pedagogical approaches can inspire meaningful conversations. Though their own interactions under the guidance of a teacher who cares about confronting ethnoracist discourses and content, 
students and teachers may be inspired to critically reflect. This critical reflection on how language can resist and inspire in the English classroom is locus of interest in the following discussion section.

\section{Discussion}

There are ways in which the narratives presented above can inform decision making for teacher educators in relation to diverse representation, pedagogy, and classroom management. These conscious decisions by English teachers to problematize ethnoracial discourses that oppress are inspiring. Through such decisions greater critical reflection can occur in relation to how language creates and sustains sociohistorical constructions of race and ethnicity at the local, national, and global levels.

\section{Representation in Curriculum}

As Georgia struggled to introduce diverse representation into the classroom with the Joy Luck Club, other researchers have found success with texts that critically approach dominant institutional discourse while also expanding ethnoracial representation. Grice, Murphy, \& Shanahan (2018) found YA novels like The Smell of Other People's Houses and Ramona Blue challenged YA readers to be conscious of White privilege and concluded these powerful counter-narratives can help fight single stories and ultimately encourage teachers to be non-complicit with inequities in the classroom. Such narratives, which disrupt dominant ethnoracial discourse, can be seen in Orlando's classroom and his choice of focusing on Caesar Chavez.

Counterstorytelling, through the pedagogical use of counternarratives, is a "vehicle through which to subvert the White dominant narrative", offer opportunities for students to actively engage in critical reading, thinking, writing, and speaking skills, all while complying to Common Core standards (Bissonnette \& Glazier, 2016). It affords secondary students and preservice teachers a way to engage in cultural and ethnoracial critique, as seen in the debate Orlando describes. Bissonnette and Glazier (2016) found that introducing counterstories in conjunction with canonical texts and conducting explicit discussion challenging the dominant discourses were excellent ways to engage students in racialized conversations in a high school ELA classroom. In addition, inviting students to craft their own counterstories have proved successful in engaging students in master narratives like Gardner's "Grendel" or Shakespeare's "Othello." This study suggested that English teachers can promote literacy practices that allow secondary students to counter the dominant cultural narratives by generating counterstories. These researchers also suggested the ELA classroom offers a safe space for students who are racially diverse to share their experiences while analyzing texts they encounter. Is it our responsibility, as "core" class teachers, to expose students to racial issues that saturate many of our modes of communication we are reading and writing in our society? It is a worthy cause to examine how English teacher educators could encourage preservice secondary English teachers to generate narratives of racial identities to function as pedagogical counterstories.

\section{Critical Reflection Assignments}

For students that might be struggling with identifying their positionality in relation to ethnoracial discourses that oppress, similar to the narratives of Ariana or Georgia, there are 
assignment options that prompt students through systematic sociological introspection to think deeply about how their beliefs, values, and perceptions might be informed by their ethnoracial understandings. McArthur (2016), who studied secondary students, used autobiographies to promote ways to employ critical media literacy in English classrooms by disrupting narratives on Black girls. She shared five different contexts in which counternarratives challenged the normalized racist and sexist views the media portray about this group. Under an overarching organization called the Black Girls Literacies Collective (BGLC), the projects emphasized counternarrative initiatives, which lead to transformative thinking and activism among the students. Researcher like this have made it possible now to study how teacher educators can champion critical racial literacy among preservice English teachers. By disrupting hegemonic discourses that oppress, English teachers can shape the language of resistance and inspiration through their conscious choices as related to representation and pedagogy.

\section{Conclusion}

Highlighting the narratives of a small sample of the ethnoracially diverse ELA teachers allowed me to analyze teachers' stories about oppression, resistance, and inspiration through a critical literacy framework. This narrative inquiry also allowed me to look more deeply at the experiences of four preservice English teachers and myself in regard to how we understand the ways in which racial discourses in the ELA classroom affect our communities and our teaching. I realized that the first step to transforming our instruction is generating these stories, critically interrogating them, disrupting normative discourse, and then healing from the miseducation we may have learned and internalized about other races and our own. However, a more important move is to go beyond personalization and examine the connections between institutions, racial discourses, and power. Becoming aware of the histories of racial oppression, their relationships to language, and how power can be sustained or reallocated through pedagogical decisions of educators can be inspiring and effective in offsetting inequities. Among English educators, we should adopt a newer model of English education to make a deliberate effort to build our racial literacies and advocate a critical race pedagogy. This means offering access to critical theory and supplementing readings especially by women of color (Kohli, 2019) in order to develop racial literacy that will prepare teachers how to talk about race and racism in the English Language Arts classroom.

\section{Limitations}

My intention to include stories that extend beyond the White/Black binary have been a fruitful cause in understanding diverse perspectives of how racial conceptualizations can affect a preservice English teacher's instruction. However, how we shared our stories depended on our positionality and our relationships with each other. The fact I was their former instructor can result in responses that they knew would please me. When the participants volunteered to be part of the study, they already understood my position in regard to racial justice education, so that knowledge may have played into how they performed or interviewed. In addition, I am visibly a person of color, so it should not be ignored that my appearance on its own can already influence how they thought about their answers. 


\section{Future research}

Beyond this, teacher educators can encourage preservice secondary English teachers to interrogate presumptions before acting upon them in the classroom Future research should explore how they can explore their family's biases and this relationship to their own identity development and positioning in today's society. Michael Cook (2019) suggested that teacher educators emphasize strengthening teacher identity development and iterate teaching as a political act (Morrell, 2005) thus situating all educators to be activists. Theories of anti-racist teaching can then be put to practice towards social transformation. Such future research directions may then empower PSETs to enact a Critical English Education (Morell, 2005) in which teachers become explicit about the role of language and literacy in disrupting existing power relations; a use of language that resists and inspires.

One of my goals as a teacher educator was to develop thoughtful and strong curriculum that negotiates race, culture, and language differences in the classroom (Jupp, Barry, \& Lensmire, 2016). I want to help form future teachers who can confidently resist and challenge the racist discourses that dominate our educational system. I believe that confronting these topics head-on is integral in joining the conversations and issues affecting our political and social climate and undoubtedly, the mindsets of our students. What they bring into our classroom is sincere curiosity often stifled by the discomfort of racial dialogue, but if preservice teachers wrestled with racial discourses first, perhaps they can truly engage their students in these discussions in a meaningful manner that may transform our racially charged world. 


\section{References}

Bender-Slack, D. (2010). Texts, talk...and fear? English language arts teachers negotiate social justice teaching. English Education, 42(2), 181-203.

Betancourt, H. \& Lopez, S. R. (1993). The study of culture, ethnicity, and race in American psychology. American Psychologist, 48(6). 629-637.

Bieler, D. (2006). Changing the subject: Building critical and compassionate communities in English and English education classrooms. Urban Education, 4(1).

Bissonnette, J. D., \& Glazier, J. (2016). A counterstory of one's own: Using counterstorytelling to engage students with the British canon. Journal of Adolescent \& Adult Literacy, 59(6), 685-694.

Borsheim-Black, C., Macaluso, M., \& Petrone, R. (2014). Critical literature pedagogy: Teaching canonical literature for critical literacy. Journal of Adolescent \& Adult Literacy, 58(2), 123-133.

Boyd, F. B., Ariail, M., Williams, R., Jocson, K., Sachs, G. T., McNeal, K., Fecho, B., Fisher, M., Healy, M. K., Meyer, T., \& Morrell, E. (2006). Real teaching for real diversity: Preparing English language arts teachers $21^{\text {st }}$ century classrooms. English Education, 38(4), 329350.

Connelly, F. M., \& Clandinin, D. J. (1990). Stories of experience and narrative inquiry. Educational Researcher, 19(5), 2-14.

Clandinin, J. \& Connelly, M. (2000). Narrative Inquiry: Experience and Story in Qualitative Research. Jossey-Bass.

Comber, B. (1999, November 18-23). Critical Literacies: Negotiating Powerful and Pleasurable Curricula--How Do We Foster Critical Literacy through English Language Arts? Paper presented at National Council of Teachers of English, Denver, CO.

Cook, M. (Feb. 2019). (Pre-Service) Teacher-Activists: Examining Pre-Service ELA Teachers'Experiences Engaging in Educational Activism. National Council of Teachers of English Assembly for Research, Birmingham, Alabama.

Foucault, M. (1972). The archaeology of knowledge. Routledge.

Freire, P. (1970). Pedagogy of the oppressed. Continuum.

Freire, P. (1989). Learning to question: A pedagogy of liberation. Continuum.

Gay, G. (1999). Ethnic identity development and multicultural education. In Sheets, R. H. (Ed.), Racial and ethnic identity in school practices: Aspects of human development (pp. 195211). L. Erlbaum Associates.

Gere, A. R. (1992). Language and reflection: An integrated approach to teaching English. Macmillan Prentice-Hall.

Glaser, B. G. (1965). The constant comparative method of qualitative analysis. Social problems, 12(4), 436-445.

Grice, K. M., Murphy, C. E., \& Shanahan, E. M. (2018). Taking out the trash: Complicating rural working-class narratives in young adult literature. The ALAN Review, 45(3), 19-28.

Grant, C. \& Agosto V. (2008). Teacher capacity and social justice in teacher education. In M. Cochran-Smith, S. Feiman-Nemser, D. J. Mclntyre, \& K. Demers (Eds.), Handbook of Research on Teacher Education: Enduring Questions in Changing Contexts (3rd ed., pp. 175-200). Taylor and Francis. 
Guzzetti, B. J., Young, J. P., Gritsavage, M. M., Fyfe, L. M., \& Hardenbrook, M.(2002). Reading, writing, and talking gender in literacy learning. International Reading Association.

Hall, L., Johnson, A. S., Juzwick, M. M., Wortham, S.E., \& Mosley, M. (2010). Teacher identity in the context of literacy teaching: Three explorations of classroom positioning and interaction in secondary schools. Teaching and Teacher Education, 26, 234-243.

Hall, S. (2001). Foucault: Power, Knowledge and Discourse. In M. Wetherell, S. Taylor, \& S. Yates (Eds.), Discourse, Theory and Practice (pp. 72-81). Sage publications.

Hollins, E. (2012). Learning to Teach in Urban Schools. Routledge.

hooks, b. (1994). Teaching to Transgress: Education as the Practice of Freedom, Routledge, New York.

Iftika, J. S., \& Museus, S. D. (2018). On the utility of Asian critical (AsianCrit) theory in the field of education. International Journal of Qualitative Studies in Education, 31(10), 935949.

Jocson, K. (2009). Steering legacies: Pedagogy, literacy, and social justice in schools. Urban Rev, 41, 269-285.

Jupp, J. C., Berry, T. R., \& Lensmire, T. J. (2016). Second-wave White teacher identity studies: A Review of White teacher identity literatures from 2004 through 2014. Review of Educational Research, 86(4), 1151-1191. DOI: 10.3102/0034654316629798

Kirkland, D. E. (2014). "They look scared": Moving from service learning to learning to serve in teacher education-a social justice perspective. Equity \& Excellence in Education, 47(4), 580-603.

Kohli, R. (2019). Lessons for teacher education: The role of critical professional development in teachers of color retention. Journal of Teacher Education, 70(1), 39-50.

Kohli, R. (2013). Unpacking internalized racism: teachers of color striving for racially just classrooms. Race, Ethnicity and Education, 17(3), 367-387.

Lac, V. T. (2017). In real time: From theory to practice in a critical race pedagogy classroom. i.e.: inquiry in education, 9(1), 1-21.

Laclau, E. (1997). Representation: Cultural representations and signifying practices (Vol. 2). Sage.

Ladson-Billings, G. (2009) 'Who you callin' nappy-headed?' A critical race theory look at the construction of Black women. Race, Ethnicity and Education, 12(1), 87-99. DOI: 10.1080/13613320802651012

Ladson-Billings, G., \& Tate, W. E. (1995). Toward a critical race theory of education. Teachers College Record, 97(1), 47-68.

Lee, V. J. (2013). Teachers of color creating and recreating identities in suburban schools. The Qualitative Report, 18(8), 1-16.

Marx, S. \& Pennington, J. (2003). Pedagogies of critical race theory: Experimentations with White preservice teachers. International Journal of Qualitative Studies in Education, 16(1), 91-110, DOI: 10.1080/0951839022000036381

Matias, C. E., \& Grosland, T. J. (2016). Digital storytelling as racial justice: Digital hopes for deconstructing Whiteness in teacher education. Journal of Teacher Education, 67(2), 152-164.

Matias, C. E., \& Mackey, J. (2016). Breakin'down whiteness in antiracist teaching: Introducing critical whiteness pedagogy. The Urban Review, 48(1), 32-50. 
Maxwell, J. A. (2012). Qualitative research design: An interactive approach. Sage.

McArthur, S. A. (2016). Black girls and critical media literacy for social activism. English Education, 48(4), 362-379.

Mclntosh, P. (1989). White privilege: Unpacking the invisible knapsack. Peace and Freedom Magazine, 10-12.

Milner, H. R. (2017). Where's the race in culturally relevant pedagogy? Teachers College Record, 119, 1-32.

Milner IV, H. R., \& Howard, T. C. (2013). Counter-narrative as method: Race, policy and research for teacher education. Race Ethnicity and Education, 16(4), 536-561.

Morrell, E. (2005). Critical English education. English Education, 37(4), 302-313.

National Center for Education Statistics. (2020). The condition of education [Compendium]. Retrieved from https://nces.ed.gov/programs/coe/

National Council of Teachers of English. (2007). Statement on anti-racism to support teaching and learning [Position statement]. Retrieved from https://www2.ncte.org/statement/antiracisminteaching/

Sleeter, C. E. (2001). Preparing teachers for culturally diverse schools research and the overwhelming presence of Whiteness. Journal of Teacher Education, 52(2), 94-106.

Sleeter, C. E. (2017). Critical race theory and the whiteness of teacher education. Urban Education, 52(2), 155-169.

Solorzano, D. G., \& Yosso, T. J. (2002). Critical race methodology: Counter-storytelling as an analytical framework for educational research. Qualitative Inquiry, 8(1), 24-44.

Strauss, A., \& Corbin, J. M. (1997). Grounded theory in practice. Sage.

Villegas, A. M., \& Lucas, T. (2002). Educating Culturally Responsive Teachers: A Coherent Approach. State University of New York Press. 